\title{
Assessing the Financial Performance of English Football Clubs: Arsenal and Manchester City
}

\author{
Siti Rochmah Ika \\ Department of Accounting \\ Faculty of Economics and Business, Janabadra University \\ Yogyakarta, Indonesia \\ ika@janabadra.ac.id
}

\author{
Kholik Udin \\ Department of Accounting \\ Faculty of Economics and Business, Janabadra University \\ Yogyakarta, Indonesia \\ kholikudin11@gmail.com
}

\author{
Joko Purwanto Nugroho \\ Department of Accounting \\ Faculty of Economics and Business, Janabadra University \\ Yogyakarta, Indonesia \\ jokopenug@janabadra.ac.id \\ Ishviati Joenaini Koenti \\ Department of Law \\ Faculty of Law, Janabadra University \\ Yogyakarta, Indonesia \\ ij.kunti@janabadra.ac.id
}

\begin{abstract}
Football is a sport and an attractive business with a high turnover of money around it. A football club may earn much from sponsorship, ticketing, and merchandise; however, it may also suffer loss from player transferred. This study aims to analyze the financial statements of professional football clubs in England, namely Arsenal and Manchester City. This study also aims to compare these football clubs' financial performance using the Z-score Altman, Springate, and Zmijewski bankruptcy prediction model. Financial statements of the two clubs in 20152017 were used as a sample. The bankruptcy prediction model analysis indicates that the two clubs have a healthy financial performance condition in the three years. The three financial performance models show consistent results in assessing the financial condition that Arsenal dan Manchester City performs healthy in reporting the business. Furthermore, the comparison between Arsenal and Manchester City's financial performance indicates that Manchester City's finances are better than Arsenal's. This paper contributes to the literature by applying the bankruptcy prediction model in the football club.
\end{abstract}

Keywords: football clubs, financial performance, $Z$ score Altman, Springate, Zmijewski, Financial Fair Play Regulation

\section{INTRODUCTION}

Football is undeniable the most popular sport in the world. Billion of fans all across the globe watch and fend for their favorite football clubs. Money circulation around the football match is massive, specifically from ticketing, sponsorship, and merchandise. Besides, many international television broadcasters compete for the broadcasting rights of the wellknown football championships. The relationship between money turn over and popular sport has made football club evolve from local sports associations to greatly capitalized public corporations [1], [2].

Europe is known for the football epicenter. The "Big Five" European football leagues (i.e., Premier League, Bundesliga, La Liga, Ligue 1, and Serie A) have shown a stable market growth in the last decade [3]. English football enjoys the honor of being defined as the most successful league in Europe. [4]. According to the University of Liverpool's annual Premier League club valuation report [5], the league clubs' value as stated in their accounts in 2018/2019 raised by $1.5 \%$ overall to $£ 14.7$ billion. Such a high value indicates that football clubs in English have experienced tremendous commercialization and have practically been evolved from amateur football associations to a business sector able to manage under financial criteria. Hence, professional football clubs are identified as a special business since they have to achieve two priorities simultaneously, i.e., succeed in the field and succeed in business performance [6].

As stated earlier, the English Premier League is the most powerful league in Europe in terms of commercialization. There are several reasons why the English league got achievement [4]. First, The Premier League record the highest revenue in 2017/2018. According to [7], the Premier League earn $€ 5.44$ billion. At the same time, Spain's La Liga and the German Bundesliga continue to compete in second-highest revenue earned with the amount of $€ 3.07$ billion and $€ 3.17$ billion, respectively. Second, in the 2017/2018 season, the average Premiership team stadium has a capacity of around 96 percent - the majority of airlines or hotels would be pleased with such capacity utilization. Third, the Premier League paid the highest salaries in Europe. According to [7], in 2017/2018, Premier League clubs' wage costs increased by $15 \%$, attaining a record level of almost $€ 3.2$ billion. It was then followed by Spain's La Liga, with the amount of wage cost $€ 2.03$ billion. Premier League clubs had a strong position in the global supply chain for football players based on the wage data. As a result, it was widely perceived as the highest quality league in Europe in terms of football quality and the most impressive in terms of the number of celebrity players it could engage. [4]. The fact that many celebrity players are involved in the league Made TV broadcasters more eye-catching, which is why the Premier 
League has the most profitable television broadcasting relationship.

Despite the substantial cash inflow of the English football clubs, the clubs' financial situations are problematic [4], [8]. [9] notes that if the English Premier League had been assessed using usual business methods, half of the clubs would be financially distressed. The explanation for this incoherence between the increased revenue potential and low profit is the fact that the large proportion of the revenues of clubs are used to maximize the clubs' sporting performance by spending on talent. Similarly, [10] states that increasing income from broadcasting rights and other funding sources, e.g., foreign capital investment, has contributed to a substantial rise in wages and transfer fees. According to [7], Premier League clubs reported increased spending in transfer fees in $2017 / 2018$, which led to the raised wage/income ratio to 59 percent and passed through the record-breaking transfers in $2016 / 2017$

The problem of financial difficulties were not faced only by the English football clubs but also the European football clubs as a whole [10]-[12]. The outcome is a serious financial crisis for the industry, with the cumulative debt of European football clubs touching multimillion euros, some clubs on the edge of bankruptcy [1], [13]. To impose more consistency and rationality in football club finances, the Union of European Football Associations (UEFA) has developed 'Club Licensing and Financial Fair Play' (FFP) principles.

In late May 2010, the UEFA officially released the FFP Regulations [14] governing football club participation in the UEFA competition. The FFP was developed to prevent professional football clubs from expending more than they receive to survive and thus face financial difficulties that could impede their long-term survival. Following sporting standards, the rule includes several important obligations on performance and financial condition of the clubs. The new financial health criteria aim at enhancing the long-term financial sustainability of the European club scenario. It changes the focus from shortterm speculative trade and single investment into a sustainable economic environment, where clubs do not run with chronic losses and pay off their debts on time. If a football club does not meet the requirements, a license will not be issued to enable the club to play in UEFA competitions. Since the Champions League and the European League are tournaments that offer great financial value to participating clubs, the inability to fulfill the licensing criteria will cause serious losses for a non-compliance club. The obedience of regulatory provisions should impede the irresponsible economic activity of clubs that weaken the UEFA's interests and the interests of all stakeholders such as players, creditors, municipalities, and fans.

The FFP Regulation implementation was accompanied by evidence from all clubs affiliated with the UEFA member countries through increased influence from leading leagues [11], including those in the United Kingdom (UK). The objective of the present study is to analyze the financial statements of English football clubs, namely Arsenal and Manchester City, using the Z-score Altman [15], Springate
[16], and Zmijewski [17] bankruptcy prediction model. The study may provide insight into some clubs' financial performance in the Premier League several years after the FFP Regulation was released.

Some studies have investigated the financial performance of football clubs in several countries for example [1], [2] in Greek, [18], [19] in Turkey, [3] in Italy, [10], [12] in France, [11] in Czech, [20] in Spanish, [4], [9], [21] in UK., and [8], [13], [22] in European continent. Different from [20], which uses only Altman [15] model, the present study also utilizes other measurements of bankruptcy, i.e., Springate [16] and Zmijewski [17], to see the consistency of the results.

\section{LITERATURE REVIEW}

\section{A. Signaling Theory}

The signaling theory was first invented by Michael Spence [23] in his research entitled Job Market Signaling. The theory involves two parties: management, who acts as a party providing a signal, and an outside party such as an investor who works as a party receiving the signal. Spence said that by giving a signal or signal, management tries to provide relevant information that can be used by investors. Then, the investor will adjust his decision according to his understanding of the signal. This theory was re-developed by Ross [24], arguing that Executives with better knowledge about their business are allowed to communicate this information to investors. This information is usually in the form of an annual financial report, which contains information on the company's condition, records, and company conditions, and can also reflect its performance.

\section{B. Previous Studies}

[4] have summarized the problem faced by British football clubs. Generally, English football is almost entirely reliant on individual investors' commitment, increasingly non-UK residents, to maintain losses and payout debt and pay the related interest costs for its continued stability. In any other sector, this condition would be considered unacceptable and unsustainable. These conditions may lead to bankruptcy. Therefore, the financial performance of football clubs needs to be examined.

Some studies have investigated the financial performance of football clubs using a variety of techniques, for example, a Malmquist productivity index [6]; Grey Relational analysis [3], [18], [19], neural network [22], financial distress model [13] and Altman financial distress model [10], [20].

[22] examines the performance of more than 200 European football clubs using a neural network. The results demonstrate that the club's financial success is determined by liquidity, debt and sporting performance. [10] utilizes Altman's prediction model of bankruptcy [15] to investigate French football clubs' financial performance. The study suggests that the bankruptcy model cannot be extended to refer to all French football clubs. It also indicates that using the updated edition of the Altman model (modified) is acceptable to French football clubs. [20] 
using the same bankruptcy model confirms that professional football's financial performance in Spain - on average and in general positions - is getting worse match after match.

While several studies have provided valuable comparisons and analyses of the different clubs' states, there is still minimum research comparing the different clubs' financial results [3]. Hence, the present study presents an application financial ratio analysis to the two clubs in the English Premier League, namely Arsenal and Manchester City, using three types of bankruptcy prediction models.

\section{METHOD}

\section{A. Population, Sample, and Data}

There are twenty football clubs included in the Premier League. This study uses purposive sampling to choose the sample. The sampling criteria are as follows. First, the football clubs are included in the big six of the league. The Premier League's big six are Manchester United, City, Liverpool, Arsenal, Chelsea, and Spur. The selection of the Big Six is based on [21], which states that British football largely represented by the big five clubs (now big six) face paradox, closer relationship with sponsorship and media generate more revenues but must spend much for talented players and have left a high debt. Second, the club is not a listed company. Third, the financial report is available during the observation period, i.e., 2015-2017. Based on the sampling criteria, Arsenal and Manchester City is the sample of the study.

\section{B. Variable Measurement}

The present study utilizes three predictions of the bankruptcy model, i.e., Altman [15], Springate [16], and Zmijewski [17], to measure the financial performance of the sample clubs. Since the sample football clubs are not listed companies, this study uses the revised Altman prediction of bankruptcy model [25]

\section{1) The Altman Model}

In this model, football clubs with a score of $Z>2.90$ are classified as healthy companies, while clubs with a $Z<1.20$ are classified as potentially bankrupt companies. Furthermore, a score between 1.20 and 2.90 is classified as a company in the grey area. The equitation is as follows [25].

$$
\begin{aligned}
Z^{\prime}=0,717 X_{1}+ & 0,847 \times 2+3,107 \times 3+0,420 \times 4 \\
& +0,998 \times 5
\end{aligned}
$$

\section{Where}

\section{$\mathrm{Z}^{\prime}$ = bankruptcy score}

$\mathrm{X} 1=$ working capital to total asset

$\mathrm{X} 2$ = retained earnings to total assets

$\mathrm{X} 3$ = earning before interest and tax to total asset

$\mathrm{X} 4$ = book value of equity to book value of debt

$\mathrm{X} 5=$ sales to total asset

\section{2) The Springate Model}

This model has a standard whereby companies with a score of $\mathrm{Z}>0.862$ are classified as healthy companies, while companies with a score of $\mathrm{Z}<0.862$ are classified as potentially bankrupt companies. The equation is as follow [16].

$$
\mathrm{Z}=1.03 \mathrm{~A}+3.07 \mathrm{~B}+0.66 \mathrm{C} 0.4 \mathrm{D}
$$

Where

$$
\begin{aligned}
& Z=\text { bankruptcy score } \\
& A=\text { working capital to total asset } \\
& B=\text { net profit before interest and taxes to total asset } \\
& C=\text { net profit before taxes to current liabilities } \\
& D=\text { sales to total asset }
\end{aligned}
$$

\section{3) The Zmijewski Model}

This model's evaluation criterion is that the greater the $\mathrm{X}$ value, the greater the company's probability of going bankrupt. In this Zmijweski analysis method, if it is negative, the company has no potential for bankruptcy. The equation of the model is as follows [17].

$$
X=-4,3-4,5 X_{1}+5,7 X_{2}-0,004 X_{3}
$$

\section{Where}

$\mathrm{X}=$ bankruptcy score

$\mathrm{X} 1=$ net income to total assets

$\mathrm{X} 2=$ total debt to total assets

$\mathrm{X} 3$ = current assets to current liabilities

\section{Research Design}

After counting each financial performance measurement of the sample clubs, this study analyses the bankruptcy score trend. In each bankruptcy prediction model, this study makes a comparison of the sample clubs.

\section{RESULTS AND DISCUSSION}

\section{A. Z' Score Altman Analysis}

As explained in the variable measurement section, the cutoff value for Z's score is 2.90 . If a company has a $\mathrm{Z}$ ' score above 2.90 , the company is financially healthy. Table 1 presents the Z' score of Arsenal and Manchester City in 20152017.

TABLE I. Z' SCORE ALTMAN

\begin{tabular}{|l|c|c|}
\hline \multirow{2}{*}{ Year } & \multicolumn{2}{|c|}{$\mathbf{Z}^{\prime}$ Score Altman } \\
\cline { 2 - 3 } & Arsenal & Manchester City \\
\hline 2015 & 4.38762 & 4.11374 \\
\hline 2016 & 4.28775 & 4.51340 \\
\hline 2017 & 4.23503 & 4.72917 \\
\hline Mean & 4.30346 & 4.45210 \\
\hline
\end{tabular}

As presented in Table I, The Z' Score value of the two clubs exceed 4 in each year of observations. Hence, the two clubs are 
financially healthy as their $Z^{\prime}$ score is above 2.90. Manchester City has a higher score of Altman $Z^{\prime}$ score on average as compared to Arsenal. There is also an upward trend in the financial performance of Manchester City from 2015 to 2017. On the other hand, there is a downward trend in the $Z^{\prime}$ score of Arsenal in the period 2015-2017. The trend of the Altman $Z^{\prime}$ score of the two clubs is presented in Figure 1.

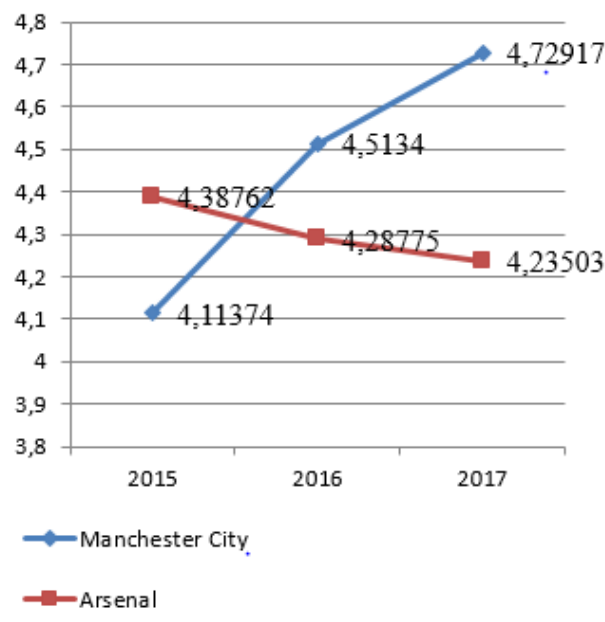

Fig. 1. The trend of the Altman Z Score

\section{B. Z Score Springate}

According to Springate [16], companies with a score of $\mathrm{Z}>$ 0.862 are classified as healthy companies, while companies with a $\mathrm{Z}<0.862$ are classified as potentially bankrupt companies. Table II presents the Springate Z score of Arsenal and Manchester City in 2015-2017.

TABLE II. Z Z SCORE SPRINGATE

\begin{tabular}{|l|c|c|}
\hline \multirow{2}{*}{ Year } & \multicolumn{2}{|c|}{ Z Score Springate } \\
\cline { 2 - 3 } & Arsenal & Manchester City \\
\hline 2015 & 1.52118 & 2.98567 \\
\hline 2016 & 1.55270 & 2.39108 \\
\hline 2017 & 2.42404 & 3.94942 \\
\hline Mean & 1.83264 & 3.10872 \\
\hline
\end{tabular}

As shown in Table II, the two clubs' Springate Z Score value is above 0.862 in each year of observations. Therefore, the two clubs are financially healthy. Manchester City has a higher score of Springate Z score on average than Arsenal, i.e., approximately 3.11 versus 1.83 . Figure 2 presents the trend of the Springate Z score of Arsenal and Manchester City. From the figure, it shows that the pattern of the trend of the two clubs is similar. However, Manchester City shows a higher financial performance as compared to Arsenal. The results of the Springate model are consistent with those in the Altman model.

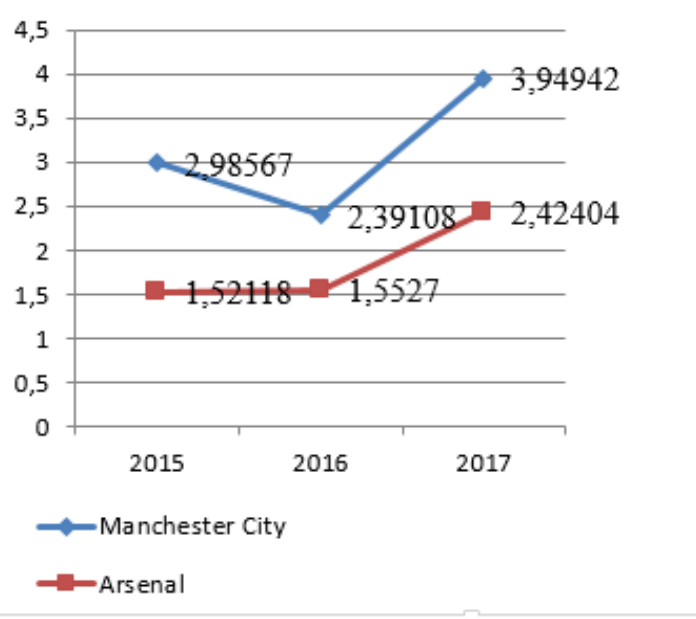

Fig. 2. The trend of the Springate Z Score.

\section{X Score Zmijewski}

The Zmijewski model [17] suggests that the lower the $\mathrm{X}$ score, the higher the financial performance. Hence, if the $\mathrm{X}$ score is negative, the company has no potential for bankruptcy. Table III shows the $\mathrm{X}$ score of Zmijewski of Arsenal and Manchester City in 2015-2017.

TABLE III. X SCORE ZMIJEWSKI

\begin{tabular}{|l|c|c|}
\hline \multirow{2}{*}{ Year } & \multicolumn{2}{|c|}{ X Score Zmijewski } \\
\cline { 2 - 3 } & Arsenal & Manchester City \\
\hline 2015 & -4.47338 & -4.18535 \\
\hline 2016 & -4.28808 & -4.09678 \\
\hline 2017 & -3.94672 & -4.13353 \\
\hline Mean & -4.23606 & -4.138553 \\
\hline
\end{tabular}

As presented in Table III, the Zmijewski X Score value of the two clubs is negative in each year of observations. Therefore, the two clubs are financially healthy. Arsenal has a slightly higher negative $\mathrm{X}$ score on average than Manchester City, i.e., approximately -4.23 versus -4.14 . These numbers suggest that the two clubs have no financial problem. Figure 3 presents the trend of the Zmijewski X score of the two clubs. As shown in the figure, there was a downward trend of financial performance of Arsenal from 2015-2017 as the negative value is getting smaller from 2015 to 2017 . The results are consistent with the trend of performance as assessed by the Altman model. The pattern of the financial performance of Manchester City is similar to those in the Springate model. The pattern of Zmijweski X Score of Manchester City is inverse U shape.

\section{Discussion}

This study analyzes the financial performance of Arsenal and Manchester City in the period 2015 -2017. The period is several years after the UEFA released the FFP Regulation. Based on the analysis of the results derived from the three 
bankruptcy prediction models, both Arsenal and Manchester City consistently show good financial performance. The results may indicate that the two clubs are profitable and able to manage their finance well. The results also may suggest that the FPP regulation's existence may strengthen the affiliated clubs' financial condition. For example, there is a threshold level for wages to revenue ratio, i.e., $70 \%$, used by UEFA as part of the FFP Regulation.

Regarding the club performance comparison, the three bankruptcy prediction models confirm that Manchester City's financial performance is better than Arsenal's. The financial performance of football clubs is correlated with their sports performance. In Premier League season 2016/2017, Manchester City was ranked number three in producing goals with 80 goals, while Arsenal was ranked number five with 77 goals. Our finding is somewhat consistent with [12] that examines the relationship between French football clubs' financial, business, and sports performance. The study found that there is a positive relationship between financial performance and sports performance.

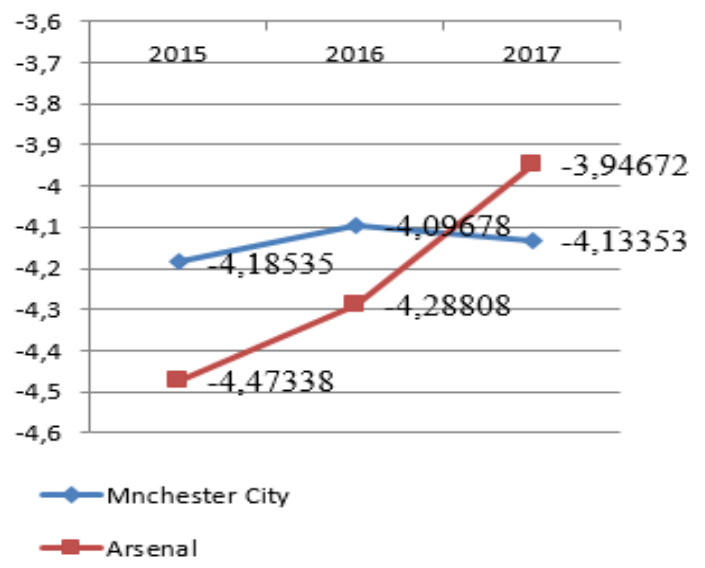

Fig. 3. The trend of the Springate Z Score.

\section{CONCLUSION}

The objective of this study is to assess the financial performance of two English football clubs, namely Arsenal and Manchester City. The three bankruptcy prediction models used in this study suggest that the two clubs' financial performance is healthy. The comparison between Arsenal and Manchester City's financial performance indicates that Manchester City's performance is better than Arsenal's. The results imply that the FPP Regulation may increase the financial performance of the affiliated clubs. As this study only compares two clubs' financial performance, future research may examine all clubs in the Premier League or at least the Big Six in the league.

\section{ACKNOWLEDGMENT}

The authors would like to express their gratitude for the research funding provided by Janabadra University.

\section{REFERENCES}

[1] P. Dimitropoulos, "The financial performance of the Greek football clubs," Choregia, vol. 6, no. 1, pp. 5-27, 2010

[2] P. E. Dimitropoulos and V. Limperopoulos, "Player contracts, athletic and financial performance of the Greek football clubs," Glob. Bus. Econ. Rev., vol. 16, no. 2, pp. 123-141, 2014, doi: 10.1504/GBER.2014.060181.

S. Pradhan, A. Boyukaslan, and F. Ecer, "Applying Grey Relational Analysis To Italian Football Clubs: a Measurement of the Financial Performance of Serie a Teams," Int. Rev. Econ. Manag., vol. 4, no. 4, pp. 1-1, 2017, doi: 10.18825/iremjournal.290668.

[4] S. Hamil and G. Walters, "Financial performance in English professional football: 'An inconvenient truth,'" Soccer Soc., vol. 11, no. 4, pp. 354-372, 2010, doi: 10.1080/14660971003780214

[5] The Baron, "Premier League Club Values 2020," 2020. [Online] Available: http://priceoffootball.com/2728-2/.

[6] I. Guzmán, "Measuring Efficiency and Sustainable Growth in Spanish Football Teams," Technol. Knowl. Transf. e-Bulletin, vol. 3, no. 1 , pp. 1-3, 2010.

[7] M. Barnard, S. Boor, C. Winn, C. Wood, and I. Wray, "World in Motion: Annual Review of Football Finance 2019," Deloitte Annu. Rev. Footb. Financ. 2019, no. May, p. 40, 2019.

P. Acero, I., Serrano, R. and Dimitropoulos, "Ownership Structure and Financial Performance in European football," Corp. Gov. Int. J. Bus. Soc., vol. 17, no. 3, pp. 511-523, 2017.

Milward, "New football directors in the twenty-first century: profit and revenue in the English Premier League's transnational age," Leis. Stud., vol. 32, no. 4, pp. 399-414, 2013.

Y. Carin, "A prediction model for bankruptcy of football clubs: The French case," Int. J. Sport Financ., vol. 14, no. 4, pp. 233-248, 2019, doi: 10.32731/IJSF/144.112019.03.

D. Procházka, "Financial conditions and transparency of the Czech professional football clubs," Prague Econ. Pap., vol. 21, no. 4, pp. 504-521, 2012, doi: 10.18267/j.pep.437.

E. Galariotis, C. Germain, and C. Zopounidis, "A combined methodology for the concurrent evaluation of the business, financial and sports performance of football clubs: the case of France," Ann Oper. Res., vol. 266, no. 1-2, pp. 589-612, 2018, doi: 10.1007/s10479-017-2631-z.

[13] D. Alaminos and M. Á. Fernández, "Why do football clubs fail financially? A financial distress prediction model for European professional football industry," PLoS One, vol. 14, no. 12, pp. 1-15, 2019, doi: 10.1371/journal.pone.0225989.

[14] UEFA, Club Licensing and Financial Fair Play Regulations. 2010

[15] E. I. Altman, "Financial Ratios, Discriminant Analysis and the Prediction of Corporate Bankruptcy," J. Finance, vol. 23, no. 4, pp. 589-609, 1968

[16] G. L. Springate, "Predicting the Possibility of Failure in a Canadian Firm," Simon Fraser University, 1978.

[17] M. E. Zmijweski, "Methodological Issues Related to the Estimation of Financial Distress Prediction Models," J. Account. Res., vol. 22, pp. 59-82, 1984.

[18] F. Ecer and A. Boyukaslan, "Measuring Performances of Football Clubs Using Financial Ratios: The Gray Relational Analysis Approach," Am. J. Econ., vol. 4, no. 1, pp. 62-71, 2014, doi: 10.5923/j.economics.20140401.06.

[19] İ. Sakinc, "Using Grey Relational Analysis to Determine the Financial Performance of Turkish Football Clubs," J. Econ. Libr. 
vol. 1, no. 1, pp. 22-33, 2016.

[20] A. Luis and F. Vázquez, "How much money would need Spanish professional football to avoid financial risk?," p. 180, 2000.

[21] T. Ozawa, J. Cross, and S. Henderson, "Market orientation and financial performance of English professional football clubs," $J$. Targeting, Meas. Anal. Mark., vol. 13, no. 1, pp. 78-90, 2004, doi: 10.1057/palgrave.jt.5740134.

[22] D. Alaminos, I. Esteban, and M. A. Fernández-Gámez, "Financial performance analysis in European football clubs," Entropy, vol. 22, no. 9, pp. 1-16, 2020, doi: 10.3390/E22091056.

[23] M. Spence, "Job Market Signaling," Q. J. Econ., vol. 87, no. 3, pp. 355-374, 1973

[24] S. A. Ross, "The determination of financial structure: the incentivesignalling approach," Bell J. Econ., vol. 8, no. 1, pp. 23-40, 1977.

[25] E. I. Altman, Corporate financial distress and bankruptcy, 3rd ed. New York: John Wiley \& Sons, Inc, 1983. 